\title{
PEMANFAATAN LIMBAH KERTAS KORAN SEBAGAI BAHAN PENGGANTI AGREGAT KASAR DALAM CAMPURAN PAPERCRETE SERTA APLIKASINYA UNTUK ELEMEN STRUKTUR RINGAN DAN NON STRUKTUR RAMAH LINGKUNGAN
}

\author{
Arqowi Pribadi ${ }^{1}$ \\ ${ }^{1}$ Program Studi Teknik Lingkungan, Universitas Islam Negeri Sunan Ampel, Jl. Jend. A. Yani 117 Surabaya \\ Email: arqowi.pribadi@uinsby.ac.id
}

\begin{abstract}
ABSTRAK
Limbah adalah bahan sisa yang dihasilkan dari suatu proses produksi, baik skala rumah tangga, industri maupun pertambangan. Kertas memiliki kandungan kimia dan alami yang bagus sehingga limbah kertas bisa didaur ulang menjadi berbagai macam bentuk. Kertas koran bekas diolah dahulu menjadi bubur kertas agar pengadukan campurannya lebih mudah. Papercrete adalah suatu material bangunan terbuat dari campuran kertas yang didaur ulang, semen portland, pasir dan air. Pengujian absorpsi dan permeabilitas pada papercrete menggunakan metode eksperimental di laboratorium setelah benda uji berumur 28 hari. Variasi campuran menggunakan perbandingan berat semen, kertas, pasir (SKP) 1:1:1; SKP 1:2:1; SKP 1:3:1; SKP 1:1:2; SKP 1:2:2; SKP 1:3:2 dengan perbandingan faktor air semen (FAS) adalah 1 . Benda uji berbentuk silinder berdiameter $7,5 \mathrm{~cm}$ dan tinggi $27,5 \mathrm{~cm}$ sebanyak 18 buah untuk uji absorpsi dan 18 buah untuk uji permeabilitas dengan tiga buah benda uji tiap variasi campurannya. Hasil pengujian absorpsi menunjukkan benda uji SKP 112 memiliki nilai absorpsi terkecil yaitu 35,64\%, sedangkan benda uji SKP 131 memiliki nilai absorpsi terbesar yaitu $85,73 \%$ dengan lama perendaman 10,5 menit. Pada pengujian permeabilitas benda uji SKP 111 memiliki nilai koefisien permeabilitas terkecil yaitu $2,13505 \times 10^{-7} \mathrm{~m} / \mathrm{dt}$, sedangkan benda uji SKP 132 memiliki nilai koefisien permeabilitas terbesar yaitu $5,17191 \times 10^{-6} \mathrm{~m} / \mathrm{dt}$ selama 1 menit. Kondisi ini menunjukkan bahwa nilai absorpsi dan nilai koefisien permeabilitas pada papercrete akan semakin besar bersamaan dengan penambahan prosentase bubur kertas ke dalam campuran. Pemanfaatan limbah kertas koran untuk pembuatan papercrete ini diharapkan mampu mengurangi permasalahan sampah kertas dan memberi keuntungan perawatan kondisi lingkungan dan sumber daya alam melalui produk material papercrete yang ramah lingkungan pada elemen struktur ringan dan non struktur seperti pembuatan dinding partisi, pengganti paving block dan rabat beton lantai.
\end{abstract}

Kata kunci: pemanfaatan limbah, kertas koran, absorpsi, permeabilitas, papercrete dan aplikasinya

\section{PENDAHULUAN}

Jenis limbah dapat berupa padat, cair, gas dan debu. Salah satu jenis limbah padat yang sering banyak dijumpai dalam masyarakat saat ini adalah kertas koran. Tingkat konsumsi kertas di Indonesia dan seluruh dunia mengalami peningkatan yang drastis. Konsumsi kertas pada tahun 2003 mencapai 5,31 juta ton, untuk tahun 2004 kebutuhan konsumsi kertas menjadi 5,40 juta ton, untuk tahun 2005 kebutuhan konsumsi kertas meningkat lagi menjadi 5,61 juta ton dan pada tahun 2009 konsumsi kertas dapat mencapai 6,45 juta ton (Pusgrafin, 2009). Dalam lingkup secara nasional (dengan asumsi jumlah penduduk 180 juta jiwa, laju produksi sampah 2 liter/orang/hari dan komposisi $6,17 \%$ ) jumlah timbunan sampah kertas di Indonesia bisa mencapai 1.599 .000 ton/tahun. Total kebutuhan kertas koran untuk para penerbit pers di dalam negeri saja pada tahun 2015 diperkirakan rata-rata mencapai 17 ribu ton per bulan dan dalam waktu setahun bisa mencapai 204 ribu ton. Sementara itu, sejalan dengan meningkatnya jumlah dan aktivitas penduduk, jumlah timbunan sampah kertas juga akan terus meningkat bersamaan dengan meningkatnya jumlah sampah pada jenis lainnya.

Penanganan sampah khususnya kota-kota besar di Indonesia seperti Jakarta, Bandung, Semarang dan Surabaya masih menggunakan paradigma 3P yaitu Pengumpulan, Pengangkutan dan Pembuangan. Sampah dikumpulkan di dalam suatu wadah dan diangkut ke Tempat Pembuangan Sampah (TPS) serta selanjutnya dibawa ke Tempat Pembuangan Akhir Sampah (TPA) hanya sekedar untuk dibuang saja. Dalam paradigma tersebut sampah masih belum dilihat sebagai sumber daya sehingga diperlukan cara pandang baru untuk melihat sampah sebagai sumber daya yang dapat 
dimanfaatkan secara optimal dalam memenuhi kebutuhan sehari-hari khususnya bidang material bangunan. Paradigma ini telah terkonsep dalam 3R yaitu mengurangi jumlah sampah (reduce), memanfaatkan kembali sampah (reuse) dan mendaur ulang kembali sampah (recycle). Salah satu jenis sampah yang belum dapat terkelola secara baik adalah jenis sampah kertas. Sampah kertas sebagai salah satu bahan baku industri daur ulang pada saat ini masih belum termanfaatkan secara maksimal sehingga hanya sekitar $70 \%$ saja yang bisa dimanfaatkan kembali ataupun didaur ulang, sedangkan jumlah timbunan sampah kertas dapat mencapai sekitar 10\% dari jumlah keseluruhan limbah sampah.

Sampah kertas memang merupakan sumber daya yang belum dimanfaatkan secara optimal, padahal jumlah dan potensinya cukup besar. Konsekuensi peningkatan konsumsi kertas akan membawa dampak tingginya limbah kertas yang dihasilkan. Besarnya jumlah limbah kertas yang ada memberikan peluang terhadap upaya pemanfaatan limbah kertas tersebut. Pemanfaatan sampah kertas baik itu untuk digunakan kembali (reuse) maupun didaur ulang (recycle) mutlak dilakukan supaya jumlah sampah kertas bisa dikurangi dan sumber daya alam pepohonan (bahan baku dalam pembuatan kertas) dapat terselamatkan secara baik dan tepat. Dalam rangka mengoptimalkan pemanfaatan limbah kertas diperlukan sekali suatu sistem pengelolaan yang baik dengan melibatkan berbagai pihak seperti kalangan masyarakat, industri maupun pemerintah. Permasalahan limbah kertas tidak lepas dari permasalahan sampah secara keseluruhan sehingga strategi pengelolaannya juga terkait dengan pengelolaan sampah kota secara keseluruhan. Dengan adanya dukungan sistem yang baik serta keterlibatan berbagai pihak, maka sampah kertas dan sampah kota lainnya dapat segera tertanggulangi secara tuntas dan juga menyeluruh.

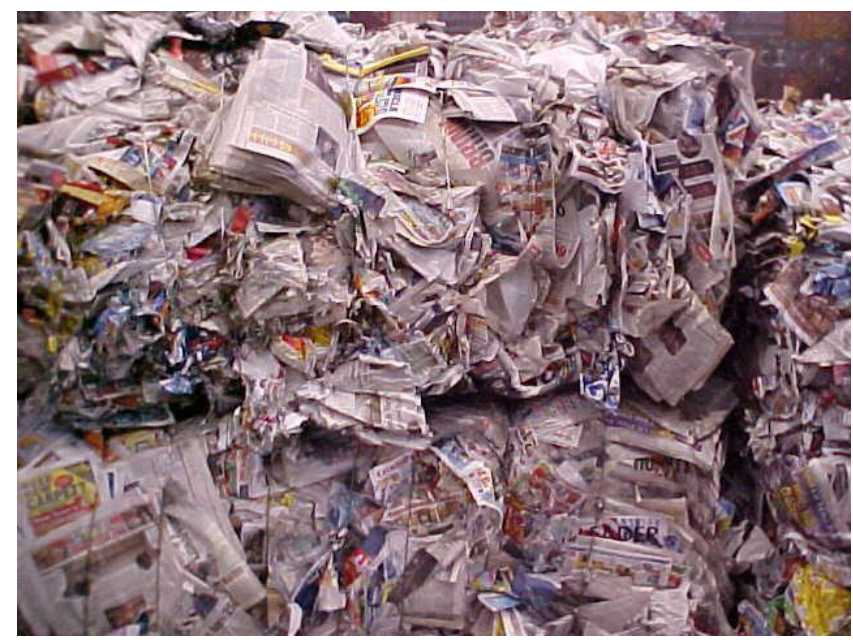

Gambar 1. Limbah kertas koran yang belum dimanfaatkan secara baik

Tabel 1. Konsumsi sampah kertas di Indonesia

\begin{tabular}{ccccc}
\hline \multirow{2}{*}{ Tahun } & \multicolumn{2}{c}{ Sampah kertas (ton) } & $\begin{array}{c}\text { Jumlah total } \\
\text { sampah kertas } \\
\text { terolah (ton) }\end{array}$ & $\begin{array}{c}\text { Stok nasional } \\
\text { kertas (ton) }\end{array}$ \\
\cline { 2 - 5 } Asal Indonesia & Impor & 1.312 .500 & 1.844 .400 \\
\hline 1992 & 430.000 & 882.500 & 1.398 .700 & 2.091 .700 \\
\hline 1993 & 526.300 & 872.400 & 1.639 .500 & 2.339 .100 \\
\hline 1994 & 630.000 & 1.009 .500 & 1.754 .150 & 2.641 .390 \\
\hline 1995 & 700.000 & 1.054 .150 & 2.277 .000 & 3.119 .970 \\
\hline 1996 & 980.000 & 1.297 .000 & & \\
\hline
\end{tabular}

(Sumber: Ditjen Cipta Karya, 1999)

Dari beberapa pertimbangan diatas, usaha mendaur ulang limbah kertas merupakan salah satu tindakan nyata yang harus dilakukan untuk mengurangi dampak buruk terhadap alam lingkungan. Keberadaan kertas koran memang sangat berlimpah dan tekstur yang dimiliki selalu memunculkan suatu ide tidak hanya berfungsi secara estetika, namun juga secara teknis yaitu bangunan akan menjadi lebih ringan, ekonomis dan nyaman. Salah satu jenis campuran yang biasanya menggunakan bahan dasar dari kertas sering dikenal dengan nama papercrete. Penggunaan bahan pencampur dari kertas ini untuk memperoleh beton ringan yang memenuhi persyaratan baik secara ekonomis maupun non-struktural. Pertimbangan secara ekonomis didasarkan atas biaya produksi untuk menghasilkan agregat ringan dan pengerjaan struktur betonnya sendiri. Secara non-struktural papercrete biasa digunakan sebagai bahan pengganti bata pada dinding, bahan pada lantai dan bermacam-macam ornamen lainnya. Penggunaan beton ringan 
pada proyek konstruksi sipil memiliki beberapa keunggulan diantaranya adalah beratnya lebih ringan dibandingkan dengan material lain. Hal ini bisa dilihat pada penggunaan beton ringan untuk dinding partisi yang akan mengurangi beban konstruksi dibanding jika menggunakan dinding bata. Dalam hal ini, tentunya papercrete memiliki kelebihan atau keistimewaan dan juga kekurangan.

\section{METODE PENELITIAN}

Metodologi penelitian adalah langkah-langkah atau metode yang dilakukan dalam penelitian suatu masalah, kasus, gejala, fenomena atau lainnya dengan jalan ilmiah untuk menghasilkan suatu jawaban yang rasional. Metode yang digunakan dalam penelitian ini ialah metode eksperimental yaitu metode yang dilakukan dengan mengadakan suatu percobaan secara langsung di laboratorium untuk mendapatkan data (hasil) dan menghubungkannya dengan variabel yang diselidiki. Dalam penelitian ini terdapat beberapa variabel yaitu variabel bebas dan variabel tak bebas. Variabel bebas dalam penelitian adalah papercrete pada variasi campuran, sedangkan variabel tak bebas adalah absorpsi dan permeabilitas pada papercrete.

\section{Bahan dasar material kertas}

Kertas bila dilihat dari segi material pembentuknya merupakan bagian rangkaian serat cellulose kayu (material berserat). Cellulose adalah bahan material terbanyak kedua di dunia setelah material batu. Bahan cellulose menjadi pembentuk utama dinding kayu tanaman hijau yang bisa menjadi bahan kain hingga kertas. Cellulose (selulosa) merupakan polimer alam yang memiliki gugusan rantai terhubung dengan molekul gula dan terbentuk dari molekulmolekul yang lebih kecil. Jaringan selulosa (cellulose fibers) dan serat yang lebih kecil dinamakan fibrils. Gugusan rantai ini mengandung banyak hidrogen yang mengikat molekul $\mathrm{OH}$ dengan sifat ikatan yang kaku, mengkristal, stabil dan sangat kuat. Jaringan fibers kering yang terjalin satu sama lain dan melekat kuat satu sama lainnya serta melekat kuat dengan ikatan hidrogen. Hal inilah yang menjadikan hidrogen sebagai dasar dari kekuatan papercrete. Berdasarkan rumusan ikatan kimia dasar pada material papercrete, maka bisa ditambahkan pula bahan-bahan lain untuk memperkuat dan memperkaya variasi adukan campurannya.

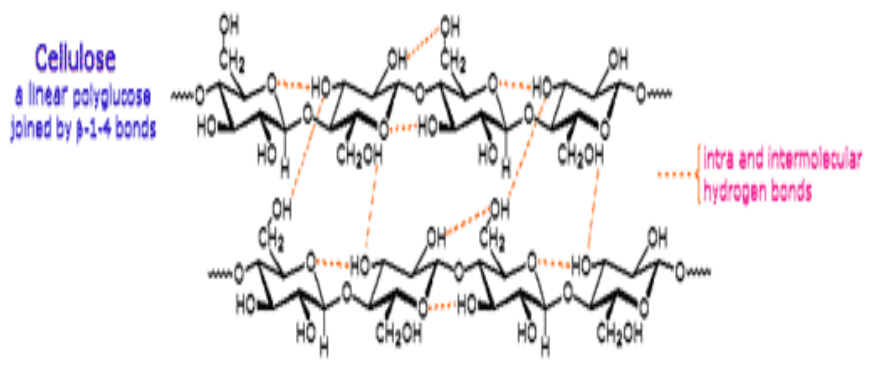

Gambar 2. Gugusan rantai cellulose

Pelapisan adukan campuran dengan semen akan memperkuat jaringannya, sedangkan penggunaan kaolinite akan membuat material lebih halus dan menimbulkan efek semi glossy. Bahan ini juga diuji dengan dipendam dalam tanah dan hasilnya bahwa material ini tahan terhadap bakteri dan tetap utuh. Perlakuan dan campuran apapun yang akan digunakan perlu diperhatikan adalah bagaimana papercrete ini menjebak udara di dalamnya. Ketika air sudah menguap dengan sempurna, maka akan terbentuk ribuan rongga-rongga kecil berisi udara. Inilah yang menyebabkan papercrete sangat ringan dan sebagai insulator terbaik. Papercrete juga memiliki respons yang jauh lebih lembut, lebih tinggi redaman dan penyerapan energinya daripada material lainnya (beton, baja, kayu). Penambahan pasir dan material lainnya hanya berakibat menjadi lebih berat walaupun tetap memiliki efek insulator yang baik sehingga material tambahan lain yang akan digunakan dapat disesuaikan dengan kebutuhannya.

\section{Benda uji papercrete}

Benda uji berupa silinder beton yang dicetak dalam pipa PVC berdiameter 7,5cm dan tinggi $27,5 \mathrm{~cm}$ untuk pengujian absorpsi dan permeabilitas pada papercrete. Penggunaan bubur kertas pada adukan campuran papercrete dilakukan variasi antara berat bubur kertas dengan berat pasir. Benda uji berjumlah 18 buah dengan variasi adukan campuran masing-masing 3 buah untuk pengujian absorpsi pada papercrete dan benda uji berjumlah 18 buah dengan variasi adukan campuran masing-masing 3 buah untuk pengujian permeabilitas pada papercrete. Contoh pembacaan kode benda uji SKP-A111 berarti adukan papercrete menggunakan campuran 1 Semen : 1 Kertas : 1 Pasir, sedangkan jika kode benda uji SKP-A132 berarti adukan papercrete menggunakan campuran 1 Semen : 3 Kertas : 2 Pasir. 
Tabel 2. Jumlah dan kode benda uji untuk pengujian absorpsi pada papercrete

\begin{tabular}{|c|c|c|c|c|}
\hline No. & Kode benda uji & $\begin{array}{l}\text { Perbandingan campuran } \\
\text { Semen : Kertas : Pasir }\end{array}$ & $\begin{array}{l}\text { Umur } \\
\text { (hari) }\end{array}$ & Jumlah \\
\hline 1. & SKP-A 111 & $1: 1: 1$ & \multirow{6}{*}{28} & 3 \\
\hline 2. & SKP-A 121 & $1: 2: 1$ & & 3 \\
\hline 3. & SKP-A 131 & $1: 3: 1$ & & 3 \\
\hline 4. & SKP-A 112 & $1: 1: 2$ & & 3 \\
\hline 5. & SKP-A 122 & $1: 2: 2$ & & 3 \\
\hline 6. & SKP-A 132 & $1: 3: 2$ & & 3 \\
\hline \multicolumn{4}{|c|}{ Jumlah benda uji untuk pengujian absorpsi } & 18 \\
\hline
\end{tabular}

(Sumber: Pribadi, 2010)

Tabel 3. Jumlah dan kode benda uji untuk pengujian permeabilitas pada papercrete

\begin{tabular}{ccccc}
\hline No. & Kode benda uji & $\begin{array}{c}\text { Perbandingan campuran } \\
\text { Semen : Kertas : Pasir }\end{array}$ & $\begin{array}{c}\text { Umur } \\
\text { (hari) }\end{array}$ & Jumlah \\
\hline 1. & SKP-A 111 & $1: 1: 1$ & & 3 \\
\hline 2. & SKP-A 121 & $1: 2: 1$ & & 3 \\
\hline 3. & SKP-A 131 & 28 & & 3 \\
\hline 4. & SKP-A 112 & $1: 3: 1$ & & 3 \\
\hline 5. & SKP-A 122 & $1: 1: 2$ & & 3 \\
\hline 6. & SKP-A 132 & $1: 2: 2$ & $1: 3: 2$ & 18 \\
\hline
\end{tabular}

(Sumber: Pribadi, 2010)

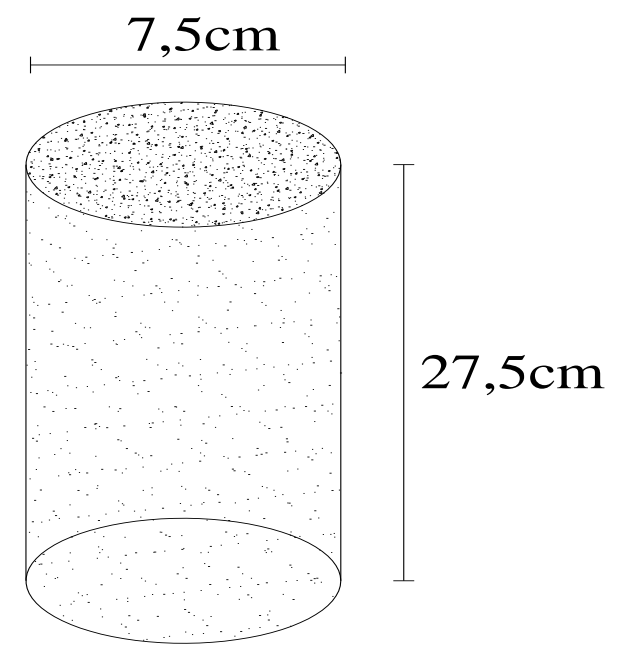

Gambar 3. Benda uji untuk pengujian absorpsi dan permeabilitas pada papercrete

\section{Metode pembuatan bubur kertas dan benda uji papercrete}

Jenis kertas yang digunakan dalam pembuatan bubur kertas adalah kertas koran bekas. Langkah-langkah pembuatan bubur kertas adalah kertas yang akan dicampur air dipotong menjadi bagian-bagian kecil untuk memudahkan dalam proses penyerapan air. Potongan kertas kemudian dimasukkan ke dalam ember yang berisi air dan direndam selama sekurang-kurangnya 1 hari. Kertas yang telah direndam selanjutnya diaduk dengan menggunakan bor yang telah dipasangi dengan pengaduk khusus. Proses pengadukan dilakukan sampai diperoleh bubur kertas yang sangat halus.

Langkah-langkah dalam pembuatan benda uji penelitian adalah menyiapkan semua material dan peralatan yang akan digunakan untuk adukan campuran papercrete. Selanjutnya menyiapkan cetakan dan kemudian menimbang masingmasing material penyusun papercrete berdasarkan pada perhitungan mix design. Langkah berikutnya ialah membuat adukan papercrete dengan cara manual, mengaduk material yang telah ditimbang menggunakan cangkul atau cetok semen dan kemudian melakukan kegiatan pengecoran dengan menuangkan adukan papercrete ke dalam cetakan serta memberi tanda untuk masing-masing sampel benda uji. Proses selanjutnya adalah melakukan pemadatan, setelah cetakan terisi penuh oleh adukan papercrete dan meratakan permukaan serta membiarkan selama $7 \times 24$ jam. Tahapan 
terakhir adalah membuka cetakan secara pelan-pelan agar benda uji papercrete tidak rusak dan kemudian melakukan perawatan dengan cara mengangin-anginkan benda uji papercrete dalam suhu ruangan sampai berumur kira-kira 28 hari (batas waktu pengujian).

\section{Metode pengujian absorpsi dan permeabilitas pada papercrete}

Metode pengujian absorpsi pada papercrete dilakukan terhadap benda uji silinder beton berdiameter 7,5cm dan tinggi $27,5 \mathrm{~cm}$. Adapun langkah-langkah pengujian absorpsi pada papercrete adalah apabila benda uji telah berumur 28 hari dan reaksi hidrasi semen dianggap selesai, selanjutnya benda uji dikeringkan dengan menggunakan oven sampai mencapai berat yang konstan (kira-kira 1 hari). Tahapan berikutnya ialah mengeluarkan benda uji dari oven dan kemudian menimbang semua benda uji menggunakan timbangan digital. Proses selanjutnya ialah merendam benda uji dengan batas waktu perendaman selama 10,5 menit; 30 menit, 60 menit, 1440 menit, 2880 menit dan 4320 menit. Tahapan terakhir adalah membuat benda uji dalam kondisi SSD (kering permukaan) dengan mengusap permukaan papercrete menggunakan kain/lap kering dan kemudian menimbang kembali masing-masing benda uji selama batas waktu perendaman tersebut diatas. Nilai absorpsi pada papercrete diperoleh dengan membandingkan perbedaan antara berat benda uji dalam kondisi SSD dan berat benda uji dalam kondisi kering oven.

Metode pengujian permeabilitas pada papercrete dilakukan terhadap benda uji silinder beton berdiameter 7,5cm dan tinggi $27,5 \mathrm{~cm}$. Adapun langkah-langkah pengujian absorpsi pada papercrete adalah apabila benda uji telah berumur 28 hari, kemudian benda uji dikeringkan dengan menggunakan oven sampai mencapai berat yang konstan (kira-kira 1 hari). Langkah berikutnya ialah selang air bertekanan dipasang pada permukaan atas benda uji dengan memberi lubang sebesar pipa selangnya. Pipa selang yang berisi air di-sealed dan diikat dengan klem pada atas permukaan benda uji. Tahapan selanjutnya adalah benda uji dikenakan air bertekanan $1 \mathrm{~kg} / \mathrm{cm}^{2}$ selama 48 jam, dilanjutkan air bertekanan $3 \mathrm{~kg} / \mathrm{cm}^{2}$ selama 24 jam dan air dengan tekanan $7 \mathrm{~kg} / \mathrm{cm}^{2}$ selama $24 \mathrm{jam}$. Proses berikutnya ialah selang air bertekanan dilepas dan kemudian dipasang selang transparan berisi air yang diletakkan pada penyangga, diamkan selama 1 menit untuk mengetahui penurunan air yang terjadi dan tingginya air jatuh. Tahapan terakhir adalah benda uji dibelah dan diukur kedalaman penetrasi air dan diameter sebaran air sehingga nilai koefisien permeabilitas dapat dihitung berdasarkan pada hukum NISS (2001).

Tabel 4. Tekanan air dan waktu penekanan pada pengujian permeabilitas papercrete

\begin{tabular}{ccc}
\hline No. & $\begin{array}{c}\text { Tekanan air } \\
\left(\mathrm{kg} / \mathrm{cm}^{2}\right)\end{array}$ & $\begin{array}{c}\text { Waktu } \\
(\text { jam })\end{array}$ \\
\hline 1. & 1 & 48 \\
\hline 2. & 3 & 24 \\
\hline 3. & 7 & 24 \\
\hline
\end{tabular}

(Sumber: Suwandojo siddiq, makalah seminar ITB, 1987)

\section{Analisis perhitungan nilai absorpsi dan permeabilitas pada papercrete}

Absorpsi beton adalah suatu peristiwa masuknya air melalui pipa-pipa kapiler atau pori-pori yang terdapat pada permukaan beton dan ini biasanya sering terjadi pada bangunan air. Hal ini merupakan masalah yang sangat serius bagi papercrete sendiri, karena masalahnya seberapa besar daya resap papercrete sendiri terhadap air tanah bila air itu meresap melalui pondasi papercrete dan merambat hingga ke dinding. Nilai absorpsi (serapan air) adalah suatu nilai dimana air dapat masuk atau menembus beton yang berpori dan nilai ini biasanya dinyatakan dalam bentuk prosentase (\%). Menurut Tjokrodimuljo (1996) besarnya serapan air pada beton dapat diukur dengan menggunakan nilai perbandingan antara berat beton dalam keadaan kering oven dengan berat beton dalam kondisi SSD selama batas waktu perendaman yang telah ditentukan dan dapat dirumuskan dengan menggunakan persamaan :

$$
\mathrm{R}=\frac{W-W_{k}}{W_{k}} \times 100 \%
$$

dengan $\mathrm{R}=$ nilai absorpsi (serapan air) pada papercrete, $\mathrm{W}=$ berat papercrete dalam kondisi $\mathrm{SSD}$ dan $\mathrm{W}_{\mathrm{k}}=$ berat papercrete dalam keadaan kering oven.

Permeabilitas adalah sifat dapat dilewati/dimasuki zat atau gas. Jadi permeabilitas beton adalah kemudahan cairan atau gas untuk melewati beton. Beton yang baik adalah beton yang relatif tidak bisa dilewati air/gas atau mempunyai permeabilitas yang rendah dan beton juga mempunyai sifat tidak bisa kedap air secara sempurna. Baik dalam ASTM maupun BS tidak ada yang mendeskripsikan secara rinci tentang pengujian permeabilitas beton, namun berdasarkan A. M. Neville dan J. J. Brooks (1987) pengujian permeabilitas beton dapat diukur dari percobaan sampel beton yang 
di-sealed dan diberi air yang bertekanan pada sisi atas saja dan meliputi aspek banyaknya air yang mengalir lewat pada ketebalan beton pada waktu tertentu (seperti disyaratkan pada SK SNI S-36-1990-03 ayat 2.2.1). Permeabilitas beton biasanya dinyatakan sebagai nilai koefisien permeabilitas yang dievaluasikan dalam persamaan NISS (2001) :

$$
\mathrm{k}=\left(\frac{A^{\prime} l}{A t}\right) \ln \left(\frac{h o}{h i}\right)
$$

dengan $\mathrm{k}=$ nilai koefisien permeabilitas papercrete, $\mathrm{A}^{\prime}=$ luas penampang pipa, $1=$ kedalaman penetrasi air, $\mathrm{A}=$ luas penampang sebaran sampel benda uji, $\mathrm{t}=$ waktu yang diperlukan, $\mathrm{h}_{\mathrm{o}}=$ tinggi air mula-mula sampel benda $u j i$ dan $\mathrm{h}_{\mathrm{i}}=$ tinggi air akhir sampel benda uji.

\section{HASIL DAN PEMBAHASAN}

\section{Hasil pengujian absorpsi pada papercrete}

Pengujian absorpsi bertujuan mengetahui besarnya air yang bisa diserap oleh papercrete dengan membandingkan antara berat yang telah melewati perendaman dalam air (kondisi jenuh kering permukaan) dengan berat dalam kondisi kering oven. Adapun waktu perendaman yang dilakukan dalam penelitian ini adalah selama 10,5 menit; 30 menit, 60 menit, 1440 menit, 2880 menit dan 4320 menit. Pada tahapan awal ini dilakukan pengamatan terhadap besarnya serapan air oleh masing-masing sampel papercrete selama batas waktu perendaman yang telah ditentukan dan kemudian dilakukan pengolahan data untuk mengetahui besarnya prosentase nilai absorpsi (serapan air).

Tabel 5. Hasil perhitungan nilai absorpsi pada papercrete

\begin{tabular}{cccccccc}
\hline \multirow{2}{*}{ No. } & Kode benda uji & \multicolumn{6}{c}{ Nilai absorpsi pada papercrete setelah direndam selama (\%) } \\
\cline { 3 - 7 } & & $\begin{array}{c}\mathbf{1 0 , 5} \\
\text { menit }\end{array}$ & $\begin{array}{c}\mathbf{3 0} \\
\text { menit }\end{array}$ & $\begin{array}{c}\mathbf{6 0} \\
\text { menit }\end{array}$ & $\begin{array}{c}\mathbf{1 4 4 0} \\
\text { menit }\end{array}$ & $\begin{array}{c}\mathbf{2 8 8 0} \\
\text { menit }\end{array}$ & $\begin{array}{c}\mathbf{4 3 2 0} \\
\text { menit }\end{array}$ \\
\hline 1. & SKP-A 111 & 44,28 & 46,42 & 47,20 & 48,98 & 50,28 & 50,57 \\
\hline 2. & SKP-A 121 & 60,74 & 62,69 & 63,72 & 67,53 & 68,76 & 69,50 \\
\hline 3. & SKP-A 131 & 85,73 & 87,22 & 88,41 & 93,57 & 95,32 & 97,07 \\
\hline 4. & SKP-A 112 & 35,64 & 36,73 & 37,33 & 38,87 & 40,22 & 40,65 \\
\hline 5. & SKP-A 122 & 49,57 & 50,42 & 51,30 & 53,79 & 55,20 & 55,92 \\
\hline 6. & SKP-A 132 & 62,23 & 63,63 & 64,85 & 68,02 & 69,45 & 70,12 \\
\hline
\end{tabular}

(Sumber: Pribadi, 2010)

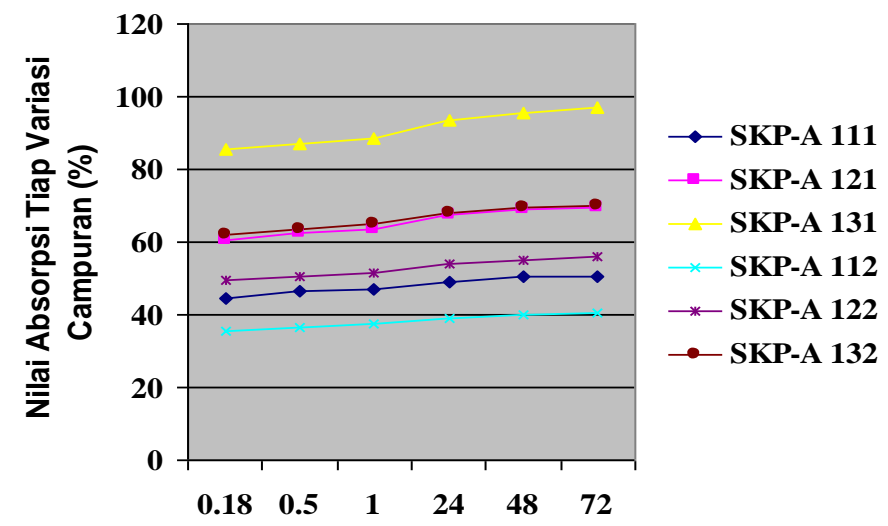

Waktu Perendaman (jam)

Gambar 4. Perbandingan nilai absorpsi pada papercrete tiap variasi campuran dengan waktu perendaman

Hasil perhitungan menunjukkan bahwa besarnya nilai absorpsi pada papercrete mulai dari variasi campuran 111,121 , 131, 112, 122 dan 132 selama perendaman 10,5 menit berturut-turut adalah 44,28\%; 60,74\%; 85,73\%; 35,64\%; 49,57\% dan 62,23\%. Pada benda uji papercrete SKP-A 112 (campuran 1 semen : 1 kertas : 2 pasir) adalah benda uji papercrete yang memiliki nilai absorpsi (serapan air) terkecil, sedangkan benda uji papercrete SKP-A 131 (campuran 1 semen : 3 kertas : 1 pasir) memiliki nilai absorpsi (serapan air) terbesar. Nilai absorpsi pada papercrete sangat dipengaruhi sekali oleh besarnya prosentase penambahan bubur kertas pada tiap-tiap variasi campuran. Pada 
campuran dengan prosentase bubur kertas paling banyak memiliki nilai absorpsi (serapan air) yang paling tinggi atau bisa dikatakan bahwa semakin banyak prosentase penambahan bubur kertas pada campuran, maka akan semakin besar pula nilai absorpsi pada beton kertas. Kondisi ini disebabkan oleh banyaknya pori-pori yang terjadi pada papercrete sehingga membuat bahan kertas lebih leluasa dalam menyerap air.

Pada adukan campuran dengan prosentase penambahan bubur kertas yang sama seperti kondisi diatas, namun ada penambahan agregat halus (pasir) pada setiap variasi campuran diperoleh hasil yang lebih baik. Hal ini disebabkan oleh pasir akan menutupi pori-pori yang terjadi pada papercrete sehingga bahan kertas lebih sulit untuk menyerap air dan kondisi ini akan berimbas dengan menurunnya nilai serapan air pada papercrete. Hal ini juga berarti bahwa kualitas papercrete akan meningkat dan semakin baik untuk digunakan bila dilihat dari parameter nilai absorpsinya. Nilai absorpsi (serapan air) papercrete pada masing-masing variasi campuran akan semakin besar seiring dengan bertambahnya waktu perendaman dan kondisi ini akan terus terjadi sampai papercrete dalam keadaan jenuh air. Hal ini sudah terlihat jelas mulai dari perendaman 48 jam ke perendaman 72 jam sudah sangat kecil nilai prosentase penambahan serapan airnya. Hal ini sudah dapat disimpulkan bahwa papercrete dalam waktu 1 hari telah mencapai kondisi jenuh air.

\section{Hasil pengujian permeabilitas pada papercrete}

Pengujian permeabilitas bertujuan mengetahui besarnya nilai penetrasi dan permeabilitas papercrete dengan cara memberi tekanan air pada benda uji. Adapun standar pemberian tekanan yang dilakukan dalam penelitian ini adalah air bertekanan $1 \mathrm{~kg} / \mathrm{cm}^{2}$ selama 48 jam, dilanjutkan air bertekanan $3 \mathrm{~kg} / \mathrm{cm}^{2}$ selama 24 jam dan air dengan tekanan 7 $\mathrm{kg} / \mathrm{cm}^{2}$ selama $24 \mathrm{jam}$. Nilai koefisien permeabilitas masing-masing variasi adukan campuran pada papercrete dapat dihitung dengan menggunakan persamaan NISS (2001) yang sudah dikombinasikan dan diintegrasikan.

Tabel 6. Hasil perhitungan nilai koefisien permeabilitas pada papercrete

\begin{tabular}{ccc}
\hline No. & Kode benda uji & $\begin{array}{c}\text { Nilai koefisien permeabilitas } \\
(\mathbf{m} / \mathbf{d t})\end{array}$ \\
\hline 1. & SKP-A 111 & $0,213505 \times 10^{-6}$ \\
\hline 2. & SKP-A 121 & $1,21904 \times 10^{-6}$ \\
\hline 3. & SKP-A 131 & $2,29956 \times 10^{-6}$ \\
\hline 4. & SKP-A 112 & $1,18858 \times 10^{-6}$ \\
\hline 5. & SKP-A 122 & $3,30194 \times 10^{-6}$ \\
\hline 6. & SKP-A 132 & $5,17191 \times 10^{-6}$ \\
\hline
\end{tabular}

(Sumber: Pribadi, 2010)

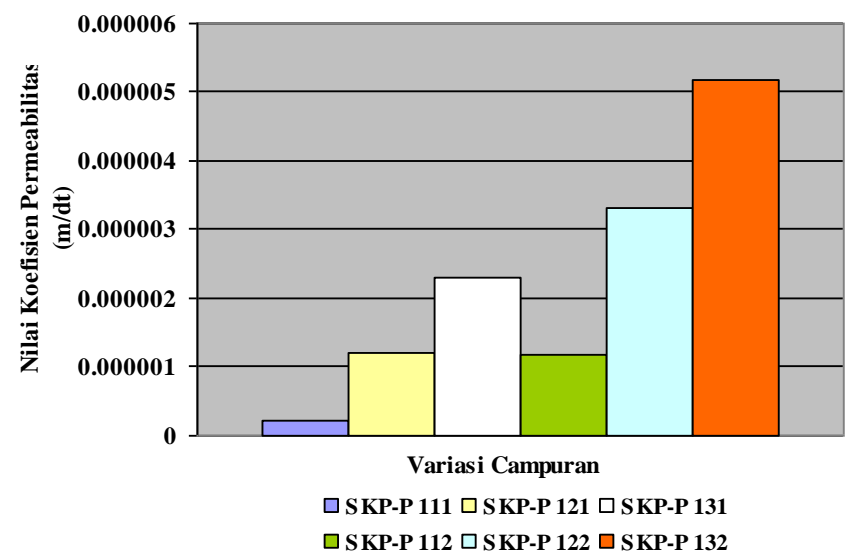

Gambar 5. Nilai koefisien permeabilitas pada papercrete tiap variasi campuran

Hasil perhitungan menunjukkan bahwa besarnya nilai koefisien permeabilitas pada papercrete mulai dari variasi campuran $111,121,131,112,122$ dan 132 selama 1 menit berturut-turut adalah $2,13505 \times 10^{-7} \mathrm{~m} / \mathrm{dt} ; 1,21904 \times 10^{-6}$ $\mathrm{m} / \mathrm{dt} ; 2,29956 \times 10^{-6} \mathrm{~m} / \mathrm{dt} ; 1,18858 \times 10^{-6} \mathrm{~m} / \mathrm{dt} ; 3,30194 \times 10^{-6} \mathrm{~m} / \mathrm{dt} ; 5,17191 \times 10^{-6} \mathrm{~m} / \mathrm{dt}$. Pada benda uji papercrete SKP-A 111 (campuran 1 semen : 1 kertas : 1 pasir) adalah benda uji papercrete yang memiliki nilai koefisien permeabilitas terkecil, sedangkan benda uji papercrete SKP-A 132 (campuran 1 semen : 3 kertas : 2 pasir) memiliki nilai koefisien permeabilitas terbesar. Nilai koefisien permeabilitas pada papercrete dipengaruhi oleh besarnya prosentase penambahan bubur kertas pada masing-masing variasi campuran. Pada campuran dengan prosentase bubur 
kertas paling banyak memiliki nilai koefisien permeabilitas terbesar sehingga bisa dikatakan bahwa semakin banyak prosentase penambahan bubur kertas pada adukan campuran, maka akan semakin besar pula nilai koefisien permeabilitas pada papercrete. Kondisi ini juga berarti kualitas papercrete akan menurun dan memiliki kekedapan yang sangat kecil serta bersifat permeabel.

Pada adukan campuran dengan prosentase penambahan bubur kertas yang sama seperti kondisi diatas, namun ada penambahan agregat halus (pasir) pada setiap variasi campurannya diperoleh hasil yang buruk. Adanya penambahan pasir pada campuran masih belum bisa menurunkan nilai koefisien permeabilitasnya. Bahkan hasil yang didapatkan malah lebih besar dibandingkan dengan tanpa menambahkan variasi pasirnya. Kondisi ini mungkin disebabkan oleh penambahan pasir ke dalam adukan campuran kurang dapat menyatu secara homogen dengan pasta semen sehingga terbentuk rongga-rongga udara yang semakin besar dan mengakibatkan kepadatannya semakin berkurang. Kondisi ini berarti kualitas papercrete akan menurun dan bersifat porous serta mudah dilalui oleh air (permeabel).

\section{Hubungan antara nilai absorpsi dengan nilai permeabilitas pada papercrete}

Grafik hubungan antara nilai absorpsi dan nilai koefisien permeabilitas tiap variasi campuran dapat digunakan untuk mencari seberapa besar prosentase penambahan bubur kertas ke dalam campuran yang paling baik diantara variasi campuran untuk menghasilkan papercrete dengan kinerja terbaik bila dilihat dari parameter nilai absorpsi dan nilai koefisien permeabilitasnya. Nilai absorpsi dan nilai koefisien permeabilitas akan semakin bertambah seiring dengan penambahan bubur kertas dan mengalami suatu penurunan apabila ada pengurangan bubur kertas ke dalam adukan campuran. Kondisi ini disebabkan oleh air yang digunakan untuk proses kimia hidrasi semen lebih cepat dan lebih banyak diserap oleh material kertas sendiri sehingga proses hidrasi semen menjadi kurang sempurna sehingga mengakibatkan rongga-rongga pada permukaan beton semakin banyak dan kepadatan menjadi semakin berkurang.

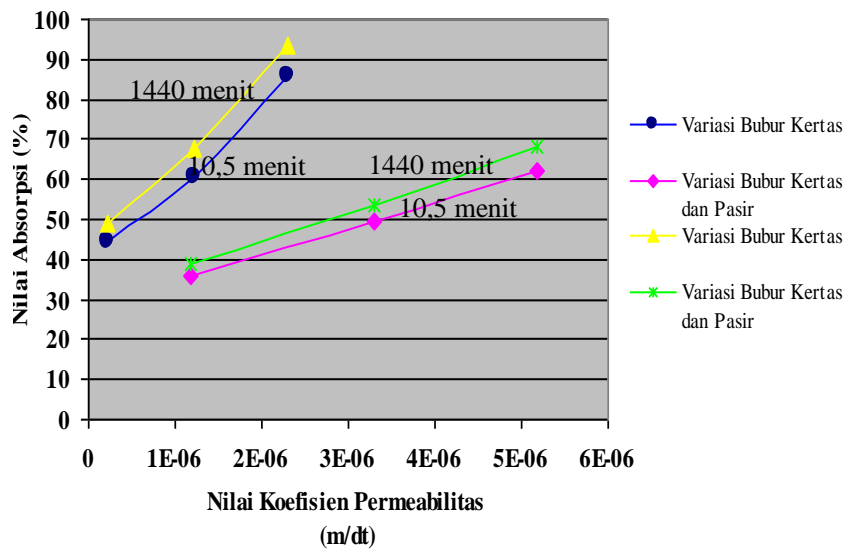

Gambar 6. Hubungan antara nilai absorpsi dengan koefisien permeabilitas selama 10,5 menit dan 1440 menit

\section{Aplikasi penggunaan papercrete pada elemen struktur ringan dan non struktur ramah lingkungan}

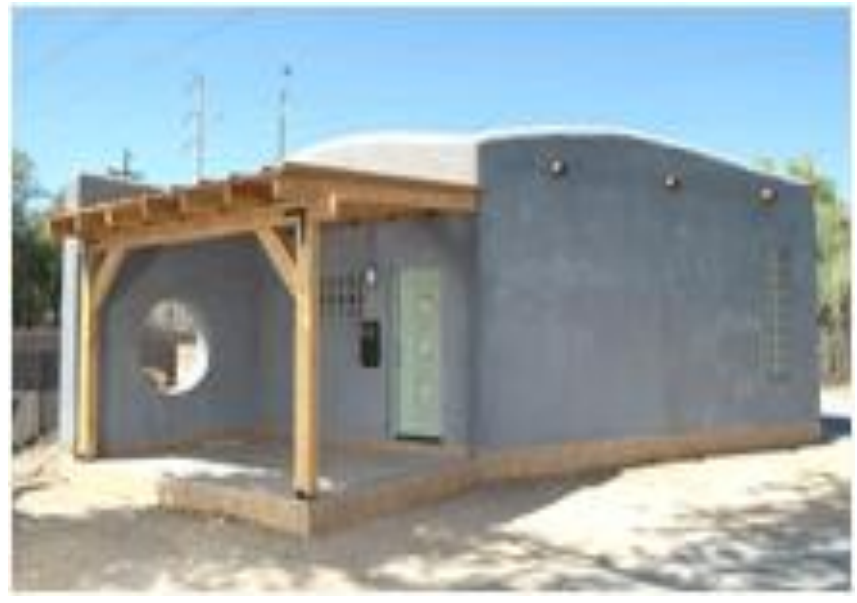

Gambar 7. Bangunan rumah sederhana yang terbuat dari papercrete 


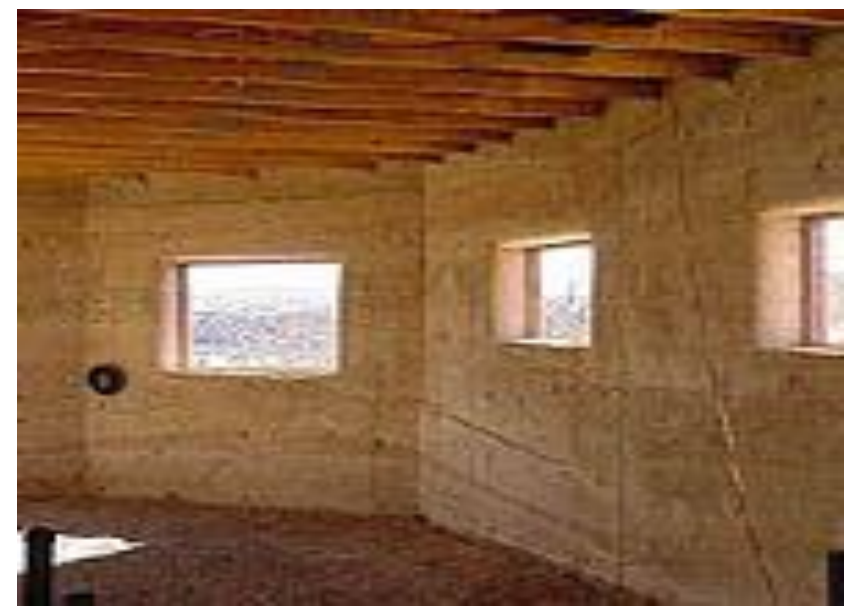

Gambar 8. Pembuatan dinding bangunan rumah berbahan papercrete

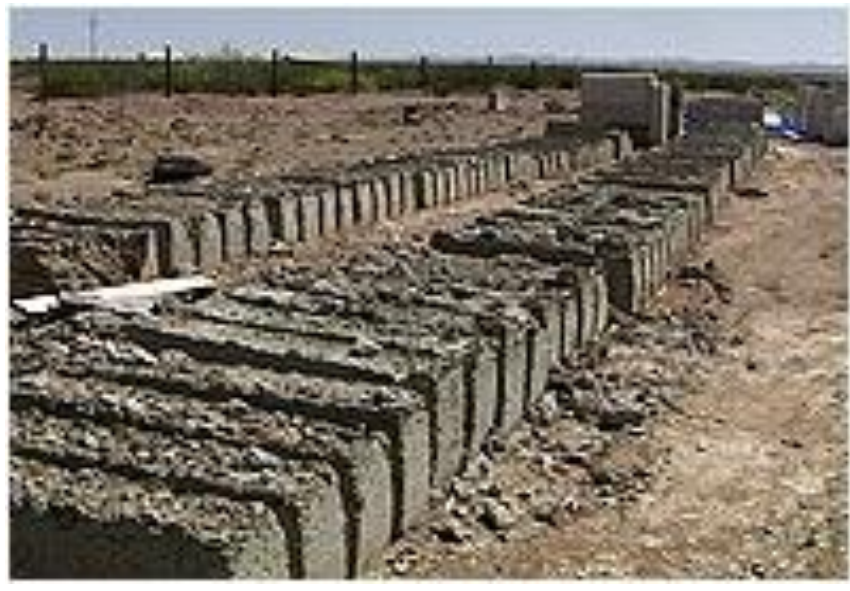

Gambar 9. Papercrete sebagai bahan pengganti paving block

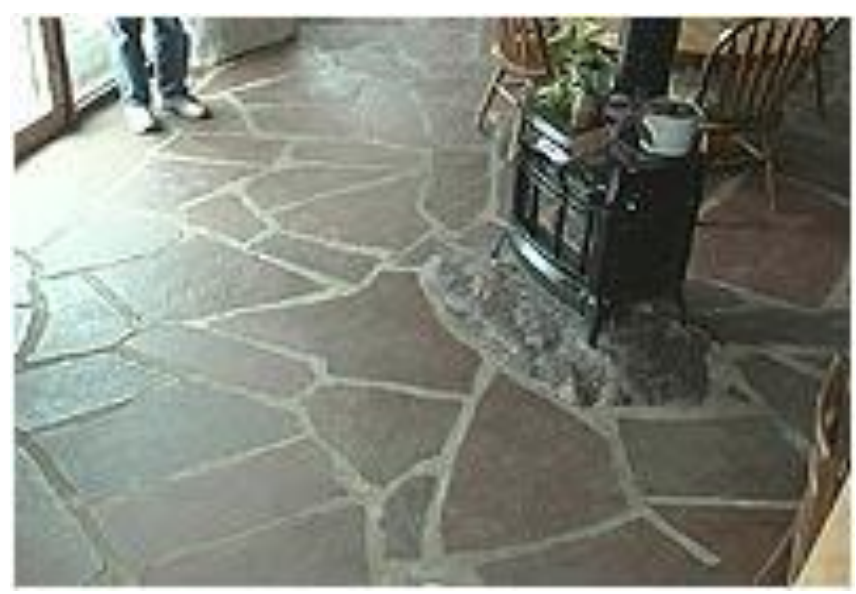

Gambar 10. Papercrete sebagai bahan rabat beton untuk lantai 


\section{KESIMPULAN}

Berdasarkan pada hasil pengujian dan pembahasan yang telah dilakukan terhadap material kertas koran, maka pemanfaatan limbah kertas koran sebagai alternatif untuk pembuatan adukan campuran papercrete dapat ditarik beberapa kesimpulan, antara lain :

1. Limbah kertas koran dapat dijadikan sebagai salah satu material alternatif untuk pembuatan adukan campuran papercrete dan sekaligus mampu mengurangi segala permasalahan sampah kertas khususnya di kota-kota besar Indonesia.

2. Survey lapangan juga menunjukkan bahwa pemanfaatan limbah kertas koran memiliki nilai ekonomis yang cukup tinggi dan beratnya sangat ringan jika dibandingkan dengan adukan campuran material lain seperti serat, kerikil, kayu dan bambu.

3. Sifat material kertas yang sangat cepat menyerap air dalam proses hidrasi semen menyebabkan papercrete memiliki kekedapan yang sangat kecil, bersifat porous dan mudah dilalui oleh air (permeabel) sehingga material kertas kurang cocok dan tepat apabila akan digunakan sebagai material yang disyaratkan dalam pembuatan beton kedap air.

4. Nilai absorpsi dan nilai permeabilitas pada papercrete akan mengalami kenaikan seiring dengan prosentase penambahan bubur kertas ke dalam masing-masing variasi campurannya. Kondisi ini disebabkan oleh material kertas yang ada di dalam adukan campuran papercrete hanya berfungsi sebagai filler atau pengisi saja tanpa memberikan daya dukung yang baik terhadap sifat absorpsi dan permeabilitasnya.

5. Hasil penelitian merekomendasikan bahwa variasi campuran yang paling baik untuk menghasilkan adukan campuran papercrete berkinerja terbaik jika dilihat dari parameter nilai absorpsi dan permeabilitasnya adalah adukan campuran dengan menggunakan perbandingan prosentase penambahan bubur kertas sangat kecil dalam tiap variasi campurannya.

\section{DAFTAR PUSTAKA}

Arief, G. Satyarno, I. dan Tjokrodimuljo, K. (2008). Kajian Pemanfaatan Limbah Kertas Koran Untuk Pembuatan Panel Papercrete. Tugas Akhir, Program Studi S1 Teknik Sipil Jurusan Teknik Sipil dan Lingkungan Fakultas Teknik Universitas Gajah Mada, Yogyakarta. Tersedia di : http://puslit2.petra.ac.id/ejournal/index.php/cef/article/view/17405.pdf.

Ditjen Cipta Karya. (1999). Kajian Teknis Pengelolaan Sampah Kertas Kawasan Perkotaan. Departemen Pekerjaan Umum, Jakarta.

Gloria, P. and Indrani, H. C. (2014). “Potensi Kertas Koran dan Gabus sebagai Alternatif Material Akustik”. Jurnal INTRA, Vol. 2, No. 2, 146-153.

Pribadi, A. (2010). Tinjauan Absorpsi Dan Permeabilitas Beton Kertas Pada Variasi Campuran. Tugas Akhir, Program Studi S1 Teknik Sipil Jurusan Teknik Sipil Fakultas Teknik Universitas Sebelas Maret, Surakarta.

Sari, TI. Maryadi dan Haviz, M. (2012). Pembuatan Bioetanol Dari Koran Bekas Dengan Hidrolisis Asam Encer (Studi Pengaruh Konsentrasi, Waktu Dan Temperatur Hidrolisis). Prosiding SNTK TOPI 2012, ISSN. 19070500. Pekanbaru.

Wahyono, S. (2014). "Pengelolaan Sampah Kertas Di Indonesia”. Jurnal Teknologi Lingkungan, Vol. 2, No. 3, 276280. 